\title{
Rinse Dosage Form
}

National Cancer Institute

\section{Source}

National Cancer Institute. Rinse Dosage Form. NCI Thesaurus. Code C42979.

A solution or suspension intended for irrig ation purposes. 